Philosophy and Progress: Vols. LI-LII, January-June, July-December, 2012 ISSN 1607-2278 (Print), DOI : http://dx.doi.org/10.3329/pp.v51i1-2.17677

\section{INFORMATION ETHICS AND ITS IMPLICATIONS FOR LIBRARY AND INFORMATION PROFESSIONALS: A CONTEMPORARY ANALYSIS}

\author{
Kazi Mostak Gausul Hoq*
}

\begin{abstract}
Information ethics provides an ethical framework for the information professionals for carrying out various information related works like acquiring, storing, processing and using of information. This has become vitally important in modern times, which has been dubbed as 'information age', because of the central role played by information in the socio-economic development of world nations. This also poses unique challenges for the library and information professionals, because the emergence of an ICT-driven information society has
\end{abstract}

\footnotetext{
* Associate Professor, Department of Information Science and Library Management, University of Dhaka. Email: kmghoq@yahoo.com
}

made their job much more challenging than before. This article explores the key questions related to information ethics and, in the light of codes of ethics promoted by national and international information organizations, discusses how information professionals could discharge their duties in an ethical and morally justifiable manner.

\section{Introduction}

The question of 'right' and 'wrong' has been troubling human beings for centuries. Almost every man or woman faces a moral dilemma of determining what is 'right' and what is 'wrong' in their everyday life. This has resulted in endless debates, arguments and discussions which show no signs of abating. In recent times, the emergence of an 'Information Society', driven by unprecedented advancements in Information and Communications Technologies (ICTs), has added a new dimension to this age-old debate on 'right' and 'wrong'. Like many other individuals, library and information professionals also are now burdened with this fundamental question: how would we determine whether what we are doing is right or wrong, ethical or unethical? Needless to say, it is very difficult, if not impossible, to come up with a definite answer to this question. Nevertheless, library and information professionals have been looking for answers to this other questions related to information ethics in myriad ways. Unprecedented explosion of information in all branches of knowledge and massive proliferation of ICT tools and techniques have raised fundamental questions about privacy, freedom of expression, right to information and accessibility, among other issues. This has made it imperative for library and information professionals to solve the problems related to ethical use of information and find out ways to serve their clients in a just and ethical manner. 


\section{Ethics and information ethics}

Ethics, also known as moral philosophy, is a branch of philosophy that involves systematizing, defending, and recommending concepts of right and wrong conduct ${ }^{1}$. Moral behaviour warrants us to take the right steps and to the right things under every circumstance. However, determining what a person should do or not do is not always an easy task. Ethics examines the rational justification for our moral judgments; it studies what is morally right and wrong, just or unjust. It leads to a set of rules of conduct for specific situations; basic ethical principles guide the development of standards for specific professions and groups ${ }^{2}$. In today's world, information plays a critical role in our everyday decision making as well as the progress and development of the society. Without accurate and timely information, it becomes quite difficult for us to make choices and plan our actions. Massive proliferation of information in every sphere of human endeavour is posing unique problems for us: we are not longer disturbed by the scarcity of information, rather we feel confused by the overabundance of information. Against this backdrop, just and rational use of information for solving our day-to-day problems is becoming increasingly challenging. It is argued that, information ethics can help us solve this problem and guide us in using information in a just way. Information ethics deals with the moral conduct of information-users based on their responsibility and their accountability ${ }^{3}$. It investigates the ethical issues arising from the generation, processing, preservation, management and use of information.

\section{Ethical dilemma faced by library and information professionals}

Like all other professionals, library and information workers also want to perform their functions in an ethical way. In the course of their professional activities, they face many dilemmas relating to the processing, preservation and dissemination of information. Determining, for example, whether to put any restrictions on the use of all computers in a public library, or to keep a particular book in the library that might offend the religions of moral sentiment of certain library users pose ethical challenges to the library officials. Charging for specialized information service in a public library, allowing making photocopies, preventing suspicious-looking persons from entering into the public library - these all are examples of scenarios which compel the library and information to take decisions based on ethical judgment. The task of providing information to the right person at the right time in the right way is not as uncomplicated as it used to be. The emergence of a plethora of ICT tools and techniques, the transformation of the library and information landscape into a highly sophisticated information and knowledge network and the diversification of demands from the users worldwide have made the task of information provision quite difficult and challenging. At the same time, inequalities among the rich and poor nations in terms of wealth creation and use have extended to the creation and use of information as well - leading to an 'informationdivide' between the information rich and poor nations. Masmoudi ${ }^{4}$, in his seminal paper "The New World Information Order", drew attention to the growing inequalities across the world in terms of information access, control and dissemination. He cited seven significant forms of inequalities existing in the world in terms of information:

1. A flagrant quantitative imbalance between North and South;

2. An inequality in information resources;

3. A de facto hegemony and a will to dominate; 


\section{A lack of information on developing countries;}

5. Survival of the colonial era; an alienating influence in the economic, social, and cultural spheres;

6. Messages ill-suited to the areas in which they are disseminated.

Similar concerns have been voiced by authorities like Smith $^{5}$, Morehouse ${ }^{6}$, Haywood ${ }^{7}$ and Buchannan ${ }^{8}$, who pointed out that, the developed countries in the northern hemisphere continue to dominate the world in terms of enjoyment of material as well as knowledge assets. They questioned the ethics of information age and its supposed free flow of information and related commodities. Therefore, as keepers and facilitators of information, library and information professionals have found themselves in a crossroads while determining how to treat their clients in the best possible and ethical manner. Since the idea of 'good' and 'bad' may vary widely from person to person and society to society, following a way which will be equally accepted and appreciated by the information-seekers (general users), information generators (authors and publishers) and information owners (holders of intellectual property rights) is not easy.

\section{Factors that influence information ethics}

While the primary concern of the library and information professionals is information ethics which is concerned with the use and misuse of information, with particular focus on intellectual property, censorship, data integrity, privacy, access to information, etc., they have to uphold their professional ethics as well which relate to the application of principles to the actions and decisions taken by information professionals. In today's world, the areas which directly and indirectly influence information ethics are:
1. Globalization: One of the most important features of modern society is globalization, which is characterised by extensive use of information and communication technologies, an increasingly open society, greater sharing of information and also greater conflict among individuals and societies in asserting their dominance over others.

2. More emphasis on individualism: People tend to be more individualistic these days; they frequently place more importance upon individual good rather than social good. As a result, there has been an increased demand for individualized and customized services from the library and information centres.

3. Privacy and information security: In this increasingly networked world, the security of public and private data held in databases, web sites and other information repositories are always at risk. People have become more worried about their privacy and libraries, as preservers and providers of sensitive information have to deal with this concern.

4. Diversification of 'information works': Unlike their predecessors, today's library and information professionals are burdened with greater and bigger responsibilities. In addition to being information providers, they now frequently have to assume the roles of educators, consultants, technology experts, translators and synthesizers, among others. They must achieve new skills and capabilities for successfully performing these duties.

5. Conflict between 'right to information' and 'ethical use of information': Many countries around the world have laws ensuring people's right to receiving and using information (Bangladesh passed 'Right to Information Act' in 2009). However, there are certain information which cannot be 
accessed by general people for security or other reasons. In many instances, library and information professionals find themselves in tricky situations where they have to strike a balance between 'restricted use of information' and 'right to information'.

6. Access to information: The issue of universal access to information may create a dilemma for many libraries. As Fernández-Molina $^{9}$ points out, many public and professional declarations refer unequivocally to free and public access to information. For example, the British Library Association code of conduct states that any individual should be granted free and public access to information. But, there is the risk that too great an emphasis on providing a service free of charge may result in funding problems that could endanger the survival of the information center. Similarly, providing a service at zero cost often results in its devaluation, which also has as a consequence the undermining of the prestige and feasibility of the profession.

7. Intellectual property rights: With the advent of new technologies, reproduction of information materials through photocopying, scanning or otherwise has become much easier. This ease of reproduction sometimes hampers the intellectual property rights of authors and publishers. It may create 'a tension between the desire of information professionals to obtain information at the lowest cost possible and the interest of the owners of this information ${ }^{10}$.

Besides, growing recognition of information as a 'raw material' for development has resulted in increasing commoditization of information. Accordingly, information is being transferred from the public sector to the private and corporate sector and 'price tags' are being attached to information, which is making it difficult for less affluent people to access and use. Schiller remarks, 'In the reallocation of information resources now occurring throughout the economy from one set of users (the general population) to another (mostly corporate business users), one principle prevails. It is the market criterion - the ability to pay. This determines who will receive and who will be excluded from the benefits of the information lubricated economy. ${ }^{11}$ Clearly, this poses new ethical challenges for library and information professionals because now they have to ascertain their roles and responsibilities in this complex 'infosphere' and determine how they could assist the underprivileged people to uphold their right to accessing and using information.

\section{What to do and what not to do: Ethical guidelines for information professionals}

In the course of performing their duties, library and information professionals are guided by some moral codes of conduct which prompt them to take certain actions at a certain time. There are a number of ethical theories which have proved to be important for guiding information professionals, like other people, to make decisions and follow a certain course of action. Simply put, these theories provide criteria for differentiating between right and wrong actions. Fallis ${ }^{12}$ explains four theories relating to information ethics, which are consequence-based theories, duty-based theories, rights-based theories and virtue-based theories. According to the consequence-based theory, what distinguishes right actions from wrong actions is that they have better consequences. In order to do the right thing, we should perform actions that have the good consequences. The main proposition of the dutybased theory is that, consequence should not be the guiding principle for determining the right and wrong action; rather, 
there are ethical duties that human beings must obey regardless of the consequences. For example, we arguably have a duty not to kill innocent people even if doing so would have very good consequences. The proponents of the rights-based theory argue that, the right thing to do is determined by the rights that human beings have. Such theories are very much consistent with information ethics as discussions of these topics are frequently framed in terms of rights, such as Library Bill of Rights of the American Library Association. The ethical theorists who support a virtue-based theory opine that, the right thing to do is determined by the virtues that human beings ought to have. According to virtue-based theories, the right thing to do is what a virtuous person would do in the same circumstances.

Library and information professionals are influenced by many factors while dealing with the ethical dilemma. What is considered to be the 'right' and 'ethical' action by one individual may appear to be 'wrong' and 'unethical' by another person. Besides, religion, age, race, nationality, social and economic background, etc. play an instrumental role in shaping the ethical viewpoint of people. However, leading international and national library and information associations like International Federation of Library Associations (IFLA), Association of College and Research Libraries (ACRL), Association of Independent Information Professionals (AIIP) and Special Libraries Association (SLA), American Library Association (ALA) and Library Association of UK (LA) - all have long standing code of ethics for guiding the information professionals in discharging their professional duties in a just and ethical way. These codes have commonly held values and ideals which focus on upholding the principles of intellectual freedom, individual privacy and confidentiality, intellectual property rights, fair and ethical use information resources, etc. However, sometime the codes become conflicting and make the task of following these codes quite difficult. Fallis argues, 'Whenever we are guided by more than one ethical principle, there is a possibility that these principles will give us conflicting advice in certain cases. 'For example, it has been suggested that the duty to protect the privacy of library patrons (e.g., by maintaining the confidentiality of their circulation records) conflicts with the duty to protect our society from terrorists ... respecting intellectual property rights can often get in the way of providing better access to information. ${ }^{13}$ It shows that, although many of the ethical dilemmas could be overcome by following the code of ethics, sometimes, in difficult circumstances, the library and information professionals will have to be guided by their personal judgment and discretion for following a particular course of action. However, the generally held view is that, providing people with their desired information is the first and foremost duty of the information professionals if it does not contradict with the most fundamental ethical principles long held by human beings like honesty, mutual respect, social good and so on. Various legal aspects and existing rules and procedures also will have to be taken into consideration. Library and information professionals must find ways to strike a balance between upholding intellectual property rights and ensuring access to information by maximum number of users. Any failure on their part in this regard will put their role as 'information intermediaries' under question. They need professional guidance, sharing of information and insights among themselves and continuous soul-searching on the questions of ethics and morality to promote and uphold information ethics in the evolving knowledge society. 


\section{Conclusion}

In today's world, people tend to consider everything in economic terms. Consequently, information, one of the main driving forces of the modern society, is increasingly being considered as a market good. But this consideration may seriously undermine people's universal rights to information and may lead to a society where only the rich and powerful will have a voice in the society. Information ethics could lead to the creation of a society where people irrespective of creed, class, economic and social standing have access to their desired information. Library and information professionals have an important role to play in the promotion of information ethics and creation of a just and equitable society. But they need to gain a deeper and more holistic understanding of ethics in general and information ethics in particular to play that role.

\section{References}

1. Internet Encyclopedia of Philosophy (2013). Ethics. Retrieved on 12 April 2013 from http://www.iep.utm.edu/ethics/

2. Kaddu, S. B. (2007). Information ethics: A student's perspective. Information Review of Information Ethics, Vol. 7 (9/2007), 1-6.

3. Chuang, C. \& Chen, J. C. (1999). Issues in information ethics and educational policies for the coming age. Journal of Industrial Technology. 15(4), 2-6.

4. Masmoudi, M. (1979). The New World Information Order. Journal of Communications (Spring), 172-185.

5. Smith, A. (1980). The Geopolitics of Information: How western culture dominates the world. London: Faber and Faber.

6. Morehouse, W. (1981). Separate, Unequal, but More Autonomous: Technology, equity, and world order in the millennial transition. Institute for World Order, Inc., New York, 1981.
7. Haywood, T. (1995). Info-Rich Info-Poor: Access and Exchange in the Global Information Society. London: Bowker-Saur.

8. Buchanan, E. A. (1999). An overview of information ethics in a world-wide context. Ethics in Information Technology, 1(1), 193-201.

9. Fernández-Molina, J. C. (2012). Ethical concerns and their place in the training of information professionals. Retrived on 10 April 2013 from http://pendientedemigracion.ucm.es/info/multidoc/ publicaciones/journal/pdf/ethical-concerns.pdf

10. Ibid.

11. Schiller, H. (1989). Culture, Inc: The Corporate Takeover of Public Expression. New York: Oxford University Press.

12. Fallis, D. (2007). Information ethics for $21^{\text {st }}$ century library professionals. Library Hi Tech, 25(1), 23-36.

13. Ibid. 